Forthcoming in American Journal of Jurisprudence (July 2018)

\title{
Abortion, Marriage and Cognate Problems
}

\author{
Cécile Laborde
}

University of Oxford ${ }^{1}$

Abstract. In Liberalism with Excellence, Matthew Kramer argues that liberal neutrality cannot adjudicate issues such as abortion, and he intimates that this problem extends to 'cognate problems' such as euthanasia, animal rights and (more unexpectedly) same-sex marriage. In this Article, I examine the sense in which marriage is a cognate problem to abortion. I suggest that liberal neutrality is indeterminate, not only about the identification of rights-bearing natural persons, but also about the identification of justice-apt social practices. I argue that the resolution of many political-moral controversies depend on contested social ontologies - claims about the nature and moral status of the particular groups and relationships that individuals form - and I illustrate this claim by reference to the rights of religious association.

Keywords. Liberal Neutrality. Abortion. Marriage. Religious Associations.

Liberal neutralists claim that controversial issues of political morality can and should be resolved by appeal to abstract political values that stand free from comprehensive ethical conceptions. One such value is the ideal that all persons must be treated according to principles of freedom and equality. As critics have observed, however, this formulation itself presumes an uncontroversial definition of what a person is. The problem is that, in debates about the legality of abortion or euthanasia, or the rights of non-human animals, it is precisely the ethical status of living beings that is at issue. There is no liberal neutralist solution to what Kent Greenawalt has called 'borderlines of status', as appeal to neutral political values cannot settle the prior question of the ontological and moral status of living beings.

\footnotetext{
${ }^{1}$ Drafts of this piece were presented at the Liberalism with Excellence workshop in Oxford (June 2017), and as a keynote lecture at the Annual Graduate Conference in Political Philosophy at the University of Pavia (September 2017). I am grateful to participants in these events for their questions, and to Jeremy Williams, Laura Valentini and Gregory Walker for their written comments.

${ }^{2}$ Kent Greenawalt, Religious Convictions and Political Choice. Oxford: Oxford University Press, 1988, Chapters 6-8.
} 
In his aptly named, excellent new book Liberalism with Excellence, Matthew Kramer deploys his sharp analytical skills to develop the most sustained version of this familiar critique of liberal neutralism. ${ }^{3}$ He shows that liberal philosophers such as John Rawls, Thomas Nagel, Ronald Dworkin, Samuel Freeman and Jonathan Quong all fail to offer a defense of the legality of abortion on neutralist grounds (such a defense, Kramer thinks, can only be made on substantive, ethical grounds). Kramer also briefly alludes to 'cognate problems' to abortion, mentioning euthanasia and animal rights, as well as - more unexpectedly - same-sex marriage. Many neutralists would balk at the latter suggestion. They might well concede that neutrality cannot adjudicate the question of whether fetuses are persons, but they would insist that no such uncertainty surrounds the status of LGBTQ citizens. Kramer is aware of this, yet he says little about the sense in which same-sex marriage is a 'cognate problem' to abortion.

The aim of this essay is to tackle precisely this question. I show that both types of controversy raise a similar issue for liberal neutralists, namely, the identification of the types of relationships and practices that are justice-apt in the first place. Liberal neutralism is indeterminate about the natural ontology of the fetus, just as it is indeterminate about the social ontology of marriage. Nor is this all: I hypothesize that many other areas of political-moral controversy depend on contested social ontologies - claims about the nature and moral status of the particular groups and relationships that individuals form - and I illustrate this claim by reference to the rights of religious association. The upshot is that borderline-of-status problems are more endemic than either Greenawalt or Kramer have recognized. This is because they concern, not only the identification of rights-bearing natural persons, but also the identification of justice-apt social practices. Disagreement between liberals and their religious critics about these and other 'cognate problems' cannot be described as unreasonable, nor is it easily tractable in public reason. I shall conclude that controversies about the status of fetuses, marriage, and religion itself raise profound, hitherto unnoticed challenges for liberal neutrality. Liberals, in my view, should be more honest and more modest in the defense of their substantive proposals.

\section{Abortion}

I begin by setting out the outlines of the neutralist position on abortion, before summarizing Kramer's objections to it. Liberal neutralist theorists typically defend women's right to have abortions, but they take seriously the depth of reasonable disagreement between pro-life and prochoice advocates. They claim to have identified a position that is appropriately neutral towards the

\footnotetext{
${ }^{3}$ Matthew Kramer, Liberalism with Excellence. Oxford: Oxford University Press, 2017, Chapter 3.
} 
controversial yet reasonable stances held by both sides. In particular, their defence of abortion is purportedly neutral towards comprehensive views - derived, for example, from conservative Catholic doctrine - that derive from the inherent sacredness of human life claims about the inviolable moral status of fetuses. The debate about abortion, in their view, can and should be conducted exclusively on terms of public reason - or at least, on terms that do not assume the truth of any comprehensive conception. By defending a qualified right to abortion, liberal law does not deny (nor, of course, affirm) that fetuses are persons. It simply asserts the right of women to decide for themselves, in a matter that is fundamental to their lives and central to their own conception of the value of life, whether or not to perform abortions. Denial of this right can only be grounded in non-public reason; whereas its affirmation, because it is neutral as to deeper disagreements about fetal personhood, is compatible both with liberal axioms of freedom and equality and with neutrality towards reasonably contested ontological and ethical matters. ${ }^{4}$

Kramer painstakingly exposes such claims to neutrality. In brief, his argument is that if as neutralists assume - it is not unreasonable to hold the view that fetuses are persons, then the liberal position cannot be justified to those who hold it. In particular, Kramer criticises three strategies to answer this challenge that have been deployed by neutralists such as John Rawls, Thomas Nagel, Ronald Dworkin, Samuel Freeman and Jonathan Quong. The first strategy asserts that conservative Catholic are unreasonable after all. This is because arguments about fetal personhood are rooted in religious doctrines and are, therefore, straightforwardly incompatible with public reason. If this were the case, the neutralist position would emerge as the only suitably public - because secular - position. However, as Kramer rightly points out, many arguments in favor of fetal personhood are in fact not defended in reference to beliefs about the divine origin of all life, and about the special sacredness of human life. In the writings of New Natural Law theorists such as John Finnis, for example, they are presented as ethical arguments concerning the biological continuity of human organisms, and the integrity of individual identity across time. ${ }^{5}$

The second neutralist strategy appeals to liberal toleration. Liberal reasonableness is rooted in a principle of mutual justification and reciprocity, such that citizens should not impose on others views that they have good reasons to reject. Conservative Catholics are intolerant insofar as they seek to do just this. But, as Kramer forcefully argues, if it is not unreasonable for conservative Catholics sincerely to think that abortion is murder - the illegitimate slaying of innocent human

\footnotetext{
${ }^{4}$ For a different account of public reason and abortion, which argues that because fetuses are excluded from the category of Rawlsian persons, public reason would recommend that abortions be legally permitted under almost all circumstances, see Jeremy Williams, 'Public Reason and Prenatal Moral Status', Journal of Ethics (2015) 19:23-52.

${ }^{5}$ Kramer, Liberalism with Excellence, p. 112-13.
} 
life -, then they have good reasons not to tolerate it. ${ }^{6}$ The third line of argument is that of compromise. This argument - associated with Rawls's much commented upon footnote on the subject $^{7}$ - is more sensitive to the different values at stake in the abortion controversy. It posits that any reasonable position on abortion will seek to balance, or compromise between, different public values, such as the right to life and women's equality. Extreme positions that fail to give adequate weight to these different values can only be held by 'unreasonable fanatics', in Quong's phrase. ${ }^{8}$ Kramer's response here is similar to the previous one. If it is not unreasonable to hold the view that fetuses belong to the class of persons who must be treated as free and equal, then we can no more compromise on their basic right to be protected from murder than we would compromise on the basic right of other persons to be so protected. ${ }^{9}$

Kramer's broader point is that the abortion controversy cannot be resolved through abstraction from the core issue that makes it so fundamental - the contested question of the status of the fetus. Any second-order move on the part of neutralists - any move that seeks to dislodge that issue from first-order questions of ethics - is doomed to fail. It is important to note that Kramer does not seek to question the liberal stance on abortion. Rather, he aims to show that the defense of such a stance necessarily involves substantive engagement with the question of fetal status. He concludes: 'when we ascertain whether the laws ... conform to the requirement of neutrality, we are consciously or implicitly adopting a position on the question whether fetuses are persons ${ }^{\prime 10}$ Liberals can only defend the right to abortion if it is, in fact, unreasonable to hold the view that fetuses should be included in the class of Rawlsian persons.

One philosopher who has engaged in such substantive debate, and whose ruminations are given extensive - if ultimately devastatingly critical - treatment is Ronald Dworkin. ${ }^{11}$ Kramer singles out two arguments in Dworkin's extended writings: the argument from incoherence and the argument from a theory of interests. Dworkin first engages with pro-life arguments, to show that they are fallacious qua internally incoherent. Kramer is scornful of Dworkin's sustained attention to unreliable moral sources such as popular views and opinion polls. But he takes seriously Dworkin's charge that religious critics are incoherent when they allow abortion in case of rape, despite their belief in fetal personhood. Kramer denies that this stance is in itself

\footnotetext{
${ }^{6}$ Kramer, Liberalism with Excellence, p. 118.

${ }^{7}$ John Rawls, 'Introduction to the Paperback Edition', in Political Liberalism. New York: Columbia University Press, 1996, pp. xxxv-lx, at liv n31.

${ }^{8}$ Jonathan Quong, Liberalism without Perfection. Oxford: Oxford University Press, 2011, p. 213.

9 Kramer, Liberalism with Excellence, p. 116. For ease of exposition, I have slightly modified and simplified the presentation of Kramer's arguments.

${ }^{10}$ Kramer, Liberalism with Excellence, p. 110.

${ }^{11}$ See, notably, Ronald Dworkin, Life's Dominion: An Argument about Abortion, Euthanasia and Individual Freedom New York: Vintage Books, 1993.
} 
incoherent by drawing on Judith Jarvis Thomson's famous violinist thought-experiment. This suggests that even if the fetus is a person with a right to life, this does not entitle him to coerce another person to provide bodily aid and sustenance. ${ }^{12}$ Dworkin's second argument is that fetuses do not have interests of their own (and therefore should have no right). Kramer instead brings up his own, more expansive, conception of interests, while suggesting - in line with his earlier influential writings - that rights are, in any case, not necessarily justified by appeal to victims' interests. ${ }^{13}$ The purpose of Kramer's engagement with Dworkin is purely critical: he does not claim to articulate an alternative view of the status of fetuses and their rights, although he suggests it is possible to provide one.

I do not intend to engage with Kramer's argument here. Let me simply raise a difficulty regarding what exactly a substantive defense of abortion rights would have to do to be successful. A thought-provoking suggestion made by Kramer is that neutrality can be salvaged if the conservative Catholic position is unequivocally exposed to be false. If it is false, it thereby becomes unreasonable. This is because if fetuses are in fact not persons, then Catholics have no good reason to deny the political value of women's right to control their own bodies. Ergo, asserting the right of women to have an abortion is neutral towards all reasonable conceptions of the good. ${ }^{14}$ So Kramer's strategy, if successful, would in effect make disagreement about abortion unreasonable. It would refute the widely accepted considered judgement that what Rawls calls the burdens of judgement apply - paradigmatically - to this and other cognate problems. To be successful in that way, the threshold of philosophical certainty must be very high. In effect, philosophers would have to show that the debate about pre-natal personhood in the $21^{\text {st }}$ century is as misguided, as philosophically flawed as, say, the debate about the moral status of slaves in the $18^{\text {th }}$ century. Fetuses are non-persons in the same unchallengeable way that slaves are persons - and any argument to the contrary is just false.

\footnotetext{
${ }^{12}$ Kramer, Liberalism with Excellence, pp. 126-129. One complication left out by Kramer is that Thomson's argument was intended to apply to ordinary cases of abortion (caused by voluntary intercourse). As her 'people-seeds' thought-experiment reveals, the issue of how the pregnancy has come about has no bearing on the general point that the right to life does not ground a right to the things needed to sustain life. Thomson, J., 'A Defense of Abortion', Philosophy and Public Affairs 1:1 (Autumn 1971): 47-66, p. 59. The question arises, therefore, whether a Thomson-style argument in favour of abortion might be neutral in the relevant sense, or whether it is grounded in assumptions (concerning the relationship between the mother and the fetus and the responsibilities that follow from it) that critics of abortion might reasonably reject. For sceptical considerations to that effect, see, eg., F. J. Beckwith, 'Does Judith Jarvis Thomson Really Grant the Pro-Life View of Foetal Personhood in her Defense of Abortion? A Rawlsian Assessment', International Philosophical Quarterly, 1 December 2014, Vol.54 (4), pp.443-451.

${ }^{13}$ Kramer, Liberalism with Excellence, pp. 134-144.

${ }^{14}$ Kramer, Liberalism with Excellence, pp. 147-150.
} 
There is an interesting puzzle here about whether any argument in ethics can be so conclusive as to lift the burdens of judgement and fix the second-order question of what makes a reasonable disagreement reasonable. As Kramer himself notes in his remarks about Dworkin, philosophers widely disagree about who has interests, how rights are grounded, what makes a human being a person, when killing is permitted, and so forth. Can this disagreement be shown to be unreasonable in the relevant sense? The threshold, as I said, seems to me to be very high. Admittedly, this need not worry Kramer unduly. Because he does not embrace the contractualist strategy of neutralists, he need not be burdened with the distinction - crucial to the latter - between what is true and what is reasonable. And he is correct to argue that unless neutralists can offer an appropriately neutral way of drawing the boundary between the true and the reasonable, between the good and the right, between questions of ontology and questions of justice, they cannot uphold their own theory of political legitimacy - one in which philosophical reasonableness is internal to political justifiability. But this is, as it were, their problem, not his.

I have digressed. I now want to proceed to my core point, which asks how pervasive the problem put to neutralists by Kramer is. Recall that the structure of the abortion problem is as follows: Resolution of the issue by appeal to (i) liberal political values depends on (ii) contested ontological premises. As Kramer notes, controversies about animal rights, as well as about euthanasia, have a similar structure. ${ }^{15}$ Their resolution depends on a contested ontology - and therefore moral status - of living beings. Neutrality about what Greenawalt has called 'borderlines of status' is not available to liberals. ${ }^{16}$ The next 'cognate problem' briefly mentioned by Kramer is same-sex marriage which - I argue - raises more complicated issues.

\section{Same-Sex Marriage}

Kramer argues that same-sex marriage, like abortion, cannot be resolved merely in public reason, by appeal to liberal political values. The core of Kramer's objection to neutralists such as Elizabeth Brake is that the liberal argument for equality between opposite-sex and same-sex unions is not neutral about the controversial issues it claims to eschew. It can succeed only if it shows the conservative Catholic position to be false - precisely what it refuses to do. ${ }^{17}$

There are several complexities here, however, that are not explored in Kramer's tersely condensed, three-page-long discussion. I first articulate two neutralist rejoinders to Kramer's

\footnotetext{
${ }^{15}$ Kramer, Liberalism with Excellence, pp. 147-150.

${ }^{16}$ Kent Greenawalt, Religious Convictions and Political Choice. Oxford : Oxford University Press, 1988, Chapters 6-8.

${ }^{17}$ Kramer, Liberalism with Excellence, pp. 150-152
} 
position: a simple argument, and a first complication. I then introduce (as a second complication) what I think is the most interesting sense in which same-sex marriage is a 'cognate problem' to abortion. This comes out, not through engagement with the conservative Catholic position, but, rather, through engagement with reasonable anti-marriage views. Let me begin with the first simple neutralist rejoinder to Kramer.

\section{The Simple Neutralist Argument}

Many neutralists simply resist the view that same-sex marriage is a 'cognate problem' to abortion. LGBTQ citizens are members of the community of free and equal persons, and they benefit from the rights that follow from such membership. To contest this is to contest the validity of the liberal political values of liberty and equality. There is no grey zone of ontological status here; no ambiguity as to whom those values apply to. Same-sex marriage is - straightforwardly - entailed by liberal political values. The case for same-sex marriage can and should be made exclusively by appeal to liberal political values (i) and it stands free from contested premises (ii).

There is no reasonable political argument against same-sex marriage, and therefore the balance of political reasons inexorably tilts towards equality between heterosexual and homosexual citizens. The burden of proof is on those who reject same-sex marriage: they must articulate acceptable political reasons for their argument. And they cannot, because opposition to same-sex marriage is rooted either in comprehensive doctrines about the sacredness of the marital bond between man and woman; or in disrespectful homophobic prejudice about same-sex sexuality. The upshot is that Catholic defenders of so-called traditional marriage unjustifiably deny same-sex couples the equal rights that they are entitled to. So the structure of what I call the simple argument is as follows:

(a) Laws must be justified by appeal to political not comprehensive values

(b) There is no valid political objection to extending marriage to same-sex couples

(c) Same-sex marriage is the only reasonable political position.

The difference with abortion is that there is no competing political value (equivalent to the right to life in the abortion debate). To this extent, Kramer is correct that the liberal position shows the conservative Catholic position to be unreasonable. Yet - the neutralist objector would continue Kramer is wrong to suggest that this threatens the liberal's own claims to neutrality. When liberal neutralists appeal to political values, and call unreasonable those who reject them, they are not giving up but rather affirming neutrality. Liberals are not moral sceptics: they are not neutral about the priority of liberal axioms of freedom and equality; they are not committed to neutrality towards 
doctrines that deny such priority. If a comprehensive doctrine denies the political value of equality, it is, ipso facto, unreasonable - ie, politically false.

(Nor - it should be noted in passing - is the liberal defense of equal marriage incompatible with a reasonable interpretation of Catholic doctrine. Rawls's theory of reasonableness demands not only acceptance of political values of freedom and equality, but also an ability to find terms of cooperation that others can reasonably accept. What is unreasonable is not the Catholic view in toto but, rather, the view that Catholic doctrine of marriage should be officially established by the state and should be the only form of marriage so established. However, a reasonable Catholic could hold that the Catholic doctrine of marriage is valid for Catholics and should be accommodated by the state - even as part of a broader marriage settlement such as equal marriage.)

What are we to make of this first neutralist rejoinder? I think it misses the force of Kramer's point. Kramer's argument, however, is elliptical, or at least ambiguous between two interpretations.

\section{A First Complication}

The neutralist argument set out above goes wrong in assuming that, to disqualify the Catholic rejection of same-sex marriage, it is sufficient to affirm the liberal value of equality. This, however, is far too quick. A conservative Catholic might plausibly respond: 'look, I am as committed as you are to the political values of liberty and equality. I object to same-sex marriage, not because I think that homosexuals are less worthy of equal respect, but because I hold a different view of the institution of marriage. Equality is all well and good, but you must first define where it applies, what it applies to'. It is only because liberals deny that marriage is primarily a unit of natural social reproduction that they think same-sex marriage is proper marriage.

On this view, the liberal defense of same-sex marriage has a slightly different structure:

(a) Marriage should not be defined as the unit of natural social reproduction

(b) Marriage affirms the value of long-term loving relationships

(c) Same-sex unions are long-term loving relationships

(d) Equality demands that same-sex unions be recognised as marriages.

Catholics need not deny (c) or even (b), nor do they need to deny the general point that similar cases must be treated equally. But they deny that same-sex and opposite-sex unions are similar in relation to the institution of marriage. For them (a) is false: marriage should be seen as a unit of 
natural social reproduction, centered on the gendered division of humanity and the natural complementarity between the sexes. ${ }^{18}$

So here the same-sex marriage debate bears a similar structure to the abortion debate. Catholics deny that they object to the political value of equality: what they contest is the definition of marriage itself. They argue that appeal to political values (i) depends on the prior settlement of what they call the ontology of marriage (ii). Catholics do not object to the priority of the political values, considered abstractly: they have a different account of where the values apply to. Their objection is structurally similar to that of critics of abortion who do not deny the political value of women's rights but instead deny that it entails a right to murder living beings who some have good reasons to consider as persons. Likewise, critics of same-sex marriage do not deny the political equality of LGBTQ citizens, but they argue that it is irrelevant to - it does not apply to - an institution that has a specific purpose unrelated (they claim) to people's sexual orientation. What critics start from is a different social ontology of marriage. The disagreement is level (ii) not level (i) disagreement. The issue cannot be resolved in public reason.

If that is the Catholic position, many liberal objections to it lose their force. Prejudice about sexual orientation is not the issue: sexual difference is. This argument does not hinge on the claim that same-sex relations are depraved or sinful, or that they cannot be accorded some kind of legal and social recognition. Rather, this argument claims that same-sex unions should not be afforded the same type of legal and social recognition as opposite-sex ones. And (as Kramer notes) this is not necessarily a religious argument. New Natural Law theorists have provided secular arguments about marriage, which cannot be dismissed out of hand as incompatible with public reason. ${ }^{19}$ If liberals are to disprove the conservative Catholic position, in other words, it is not enough to appeal to the political value of equality: a more substantive engagement is required. Here we get closer to Kramer's point. To show that the Catholic position is false, it is not sufficient to show that it conflicts with equality. Liberals need to refute (a): the defense of marriage as a unit of social natural reproduction. Can this be done while respecting the strictures of neutrality?

Kramer suggests (but does not demonstrate) that it is possible to show that the argument only works 'on the basis of fallacies'. ${ }^{20}$ One possible line of argument here is similar to Dworkin's argument from incoherence in the case of abortion. On this view, liberals do not need to embrace nor refute the critics' premises. They merely need to point out that even if, pro arguendo, the

\footnotetext{
${ }^{18}$ Sherif Girgis, Robert. P. George \& Ryan. T. Anderson, 'What Is Marriage?', Harvard Journal of Law \& Public Policy 2010, 34: 248-87. For an interesting discussion, see Greg Walker, 'Public Reason Liberalism and Sex-Neutral Marriage: a Response to Francis J. Beckwith', Ratio Juris, Vol. 28, No 4, December 2015 (486-503).

${ }^{19}$ Kramer, Liberalism with Excellence, p. 151.

${ }^{20}$ Kramer, Liberalism with Excellence, p. 151.
} 
premises are correct, they do not logically entail the purported inference. Liberals can engage in substantive philosophical and ethical argumentation - perhaps in the form of what Rawls called 'reasoning from conjecture' - but only to show that their critics are internally incoherent. In the literature about same-sex marriage, a demonstration of this fallacy has been called the 'But You Can't Be Serious' argument. ${ }^{21}$ Liberal critics have charged that conservative Catholics cannot seriously mean that marriage is about natural social reproduction, because this would entail the view, which Catholics reject, that infertile opposite-sex couples do not have the right to marry. Not all traditional unions are reproductive, and so conservative Catholics cannot be serious when they say that the only ground for their defense of traditional marriage is their commitment to natural reproduction. (On this subject, there is a lively exchange between Robert George and Andrew Koppelman on the question of whether infertile sexual organs are still 'intended' for reproduction, or whether they are as connected to reproduction as an unloadable gun is to murder). ${ }^{22}$ At any rate, the point of liberal critics such as Koppelman is that conservative Catholics are unreasonable because their view of marriage is internally incoherent.

If this is correct, the neutralist argument from incoherence remains neutral in the relevant sense. It avoids engagement with the deeper premises of the Catholic argument, and only shows its conclusions to be fallacious. Of course, a further step would be to say that if the premises do not support the conclusion, something else (some illicit or invisible premise) must be doing the work. Some have argued, for example, that New Natural Law arguments are incomprehensible marred with fallacies - unless they are framed with a theistic framework. ${ }^{23}$ But neutralists need not take that step to refute critics on purely logical grounds, and might propose a version of what Kramer calls 'neutrality after all'.

It might be the case that liberal neutralism can be defended in this way. Still, we are not out of the woods. For there is a second complication.

3. A Second Complication

\footnotetext{
${ }^{21}$ Vaughn Bryan Balzly, 'Same-Sex Marriage, Polygamy, and Disestablishment', Social Theory and Practice, Vol. 38, No. 2 (April 2012), 333-362, at pp. 345-48.

22 Andrew Koppelman, 'Is Marriage Inherently Heterosexual?', American Journal of Jurisprudence, Vol. 42, 1997, pp. 51-96, at pp. 62-70. See also Stephen Macedo, 'Homosexuality and the Conservative Mind', Georgetown Law Journal, Vol. 84 (December 1995), pp. 261-300; Gerard V. Bradley and Robert P. George, 'Marriage and the Liberal Imagination', reprinted in R. P. George, In Defense of Natural Law. Oxford: Oxford University Press, 1999, Chapter 8.

${ }^{23}$ Nicholas C. Bamforth \& David A.J. Richards, Patriarchal Religion, Sexuality and Gender: A Critique of New Natural Law. Cambridge: Cambridge University Press 2008.
} 
The salient question is whether neutralists, in their own positive defense of same-sex marriage, appeal only to political values. The answer is negative. Insofar as liberals endorse state recognition of certain relationships, they - just like Catholics - need to identify the salient relationships to which the political values apply. Liberals define marriage as long-term loving relationships (ii). But what is so special about long-term loving relationships, which justifies that they should be granted the imprimatur of state recognition? Why should the state favor amorous relationships, instead of relationships of friendship and other networks of care and intimacy? And - from another perspective - why should officially-recognized love be bi-amorous, instead of poly-amorous? New Natural Law critics such as Robert George are, I think, correct to turn the tables on liberals and challenge them to articulate a defense of their doctrine of marriage. ${ }^{24}$

Philosophers such as Véronique Munoz-Dardé, Tamara Metz, Elizabeth Brake and Clare Chambers have suggested that state recognition of marriage - whether or not it is extended to same-sex couples - is itself incompatible with liberal neutrality. ${ }^{25}$ The liberal view of marriage is amato-normative - it privileges permanent, bi-amorous, exclusive relationships - and therefore is not neutral towards reasonable conceptions of the good. As Chambers has suggested, the institution of marriage is inevitably perfectionist, in the sense that it promotes a conception of the good that directly conflicts with alternative reasonable conceptions. Among the latter, she lists conceptions of the good life that value feminism, impermanence, celibacy, or non-monogamy. ${ }^{26}$ Those who hold such conceptions - much like the reasonable Catholics I described earlier - do not seek to impose them onto others. Yet - by contrast to reasonable Catholics - they are not treated with equal respect if the state privileges those citizens who are in long-term loving relationships.

The upshot for liberal neutralists is this. Even if liberal neutralism remains unaffected by its confrontation with Catholic doctrines - where the burden of reasonableness shifts to the latter -, it does not emerge unscathed from its confrontation with other conceptions of the good that are not obviously unreasonable. Liberal marriage - open both to opposite- and same-sex couples - amounts to the 'establishment' of a contested conception of the good; and it is no surprise that liberal neutralists have called for its 'dis-establishment', on the model of religious

\footnotetext{
${ }^{24}$ George et al., 'What Is Marriage?', p. 251.

25 Véronique Munoz-Dardé, 'Rawls, Justice in the Family and Justice of the Family', The Pbilosophical Quarterly, 1998 (48): 335-352; Tamara Metz, Untying the Knot: Marriage, the State and the Case for Their Divorce. Princeton: Princeton University Press, 2010; Elizabeth Brake, Minimizing Marriage: Marriage, Morality, and the Law. Oxford University Press, 2012; Clare Chambers, Against Marriage. An Egalitarian Defense of the MarriageFree State. Oxford; Oxford University Press, 2017. See also Michael Sandel, Justice: What's the Right Thing to Do? New York: Farrar, Straus and Giroux, 2009, pp. 244-69.

${ }^{26}$ Chambers, Against Marriage, 55-56
} 
disestablishment. ${ }^{27}$ But if, instead, liberals want to extend existing marriage to same-sex couples on the ground of equality, they first need to provide a substantive defense of the good of amatonormativity. ${ }^{28}$ It might be a defensible and attractive conception of the good (I do not engage with this question here) but it is not neutral towards all reasonable conceptions of the good, and it therefore fails at the bar of neutrality.

In the end, then, the liberal view depends on what we might call a contested social ontology of marriage - by analogy with the contested natural ontology of the fetus. (To clarify: I use the term social ontology in a loose sense, as establishing what exists in the social world. It is not a naturalist or metaphysical account of how things are; social ontologies are rooted in social interpretations of the institutions and relationships that make up the social world). ${ }^{29}$ The structure of the same-sex marriage debate, then, is as follows: resolution (i) in public reason depends on (ii) a contested social ontology of marriage.

My suspicion is that this problem generalizes. I hypothesize that many areas of political-moral controversies depend on contested social ontologies - claims about the nature of the particular groups and relationships that individuals form. Catholics claim that they do not object to the value and importance of the political idea of equality, but instead ask where it applies to. I suspect that this claim is valid across a number of politico-legal controversies. Even if we accept the priority of the political values of justice, public reason is indeterminate about where and how these values apply: it needs an account of the social ontology of relevant relationships and institutions. This undermines claims to neutrality at quite a profound level: dissenters cannot easily be called unreasonable if they hold an alternative ontology. In my final section, I illustrate this point by reference to the rights of religious associations.

\footnotetext{
${ }^{27}$ Metz, Untying the Knot.

${ }^{28}$ See, for example, Stephen Macedo, Just Married: Same-Sex Couples, Monogamy, and the Future of Marriage. Princeton: Princeton University Press, 2015.

${ }^{29}$ I borrow the term 'social ontology' from Christian List \& Laura Valentini, 'The Methodology of Political Theory', in Herman Cappelen, Tamar Szabó Gendler, and John Hawthorne (eds.) The Oxford Handbook of Philosophical Methodology. Oxford Handbooks in Philosophy. Oxford University Press, Oxford, 2016. They write: 'Social ontology is primarily a positive and explanatory field rather than a normative or evaluative one. Its relevance to political theory lies in the fact that political theory cannot get off the ground unless we are clear about what entities and properties exist in the social world'. I agree that political theory needs a prior ontological account, but I would reject the description of ontologies as pertaining to the domain of positive factuality. In my view, any such descriptions are through and through normative - there is no fact of the matter about whether foetuses are persons, or about whether marriage is a loving union - such 'facts' are socio-ethical, not natural, facts and are inevitably mediated by normative views. The key point, however, that they are not necessarily mediated by fully comprehensive views, so both natural and social ontologies are awkwardly situated on the political-comprehensive continuum.
} 


\section{The Rights of Religious Associations}

Let us look at a recent area of legal controversy: what is called, in US law, 'the ministerial exception': the right held by churches not to be subject to labor laws - notably anti-discrimination regulations - in their choice of ministers. What will become clear is the extent to which controversies about the justice of such exemptions depend on reasonably contested matters of social ontology. Again, I set out three different ways to interpret the debate, starting with a simple neutralist argument, and introducing two complications.

\section{The Simple Neutralist Argument}

It is aptly set out by Jonathan Quong. Quong argues that disagreement about the justice of allowing the Catholic Church to discriminate on the basis of gender when employing priests can be resolved in public reason. Those who defend the ministerial exception invoke the political ideals of freedom of association and freedom of religion. Those who reject it appeal to equality of opportunity and non-discrimination. They disagree about how to rank and weigh these values, and they reach different substantive conclusions about the case at hand. But as long as they appeal to freestanding political principles, they respect the ideal of public reason. ${ }^{30}$ In sum, members of religious groups can appeal to the liberal political value of freedom of association to justify some of their cherished collective practices and traditions.

\section{A First Complication}

A first line of objection might go as follows. To cast the debate about the ministerial exception as a debate about the scope of freedom of association implies that churches are voluntary associations. But this is rejected by conservative religious believers, for whom churches are transhistorical, transgenerational, organic entities whose authority cannot be exclusively derived from the consent of present members. Taking their cue from $19^{\text {th }}$-century doctrines of group personality and church autonomy, they argue that church membership is importantly different from membership in ordinary civil society associations. To use Richard Garnett's phrase, churches 'are not like the Boy Scouts ${ }^{31}$ : typically, individuals are born into churches, their lives are comprehensively organized by them, and authority within churches is vertical and hierarchical. The

\footnotetext{
30 Jonathan Quong, Liberalism without Perfection. Oxford: Oxford University Press, 2011, pp. 205-6.

31 Richard W. Garnett, “Are Churches like the Boy Scouts?,” St. John's Legal Comment 22 (2007): 515.
} 
liberal framing of the debate about the ministerial exemptions (and cognate debates about collective religious rights) relies on a controversial sociological and ontological account derived from Lockean individualism. To require religious believers to make their case in terms of public reason, by appeal to freedom of association, directly conflicts with the alternative, more communitarian social ontology that they endorse. And it is unclear that many - if any - of the traditional prerogatives of churches will survive their 'translation' into the liberal language of associational freedom.

Should this objection worry liberals? Phrased in this way, I do not think it should, for liberals have a response readily available to them. In brief, the communitarian theory of church autonomy is not compatible with the political liberal premise that society should be seen - from the perspective of justice - as a scheme of cooperation between free and equal individuals. Not all civil society associations should be described as voluntary, of course: think of the case of parental and other caring relationships, for example. But generally, liberal law has good reasons to construct most associations - including religious associations - as being composed of free and equal individuals, and to derive their rights from the rights of their members. This need not conflict with the view that individuals do in fact experience their membership of this or that association as non-voluntary. The purpose of the law is not to describe sociological or psychological facts. Just as, in practice, individuals might not experience their marriage as a revocable contractual arrangement between two individuals, it is important that the law interpret marriage as if it were one. Marriages break down, spouses fights, and children and vulnerable spouses need to be protected. Likewise for churches. Religious believers might not experience church membership as being grounded in their individual will and consent. But it is important that their rights of exit their own freedom to associate and dissociate - be protected by the law, should they need it to exercise it.

So the frequently voiced complaint that liberal law relies on an inaccurate and distorted description of the social ontology of relationships and communities - and the connected complaint that liberal law is based on an ethnocentric, Protestant view of what religion is - misses its target. The point of liberal ontology is not purely descriptive but interpretive and normative through and through. The alignment between liberal normative values and a broadly individualistic social ontology of religion is only to be expected. Those who reject it reject a basic premise of the liberal approach to justice, and are unreasonable to this extent. It would be unreasonable, that is, to shelter large areas of social and associational life, just because it is religious, from the reach of liberal justice. Therefore, the liberal embrace of a broad individualistic ontology is compatible with 
neutrality 'after all'. So far, so good. Yet we are not out of the woods, for there is a second complication.

\section{A Second Complication}

It is this. Endorsement of a broadly individualistic ontology of religious associations does not settle the question as to which rights such groups should have over their members or over outsiders. Recall Quong's framing of the ministerial exception controversy. In his view, it is reasonable to invoke the political value of freedom of association to deny access to the priesthood to women. The problem here is that it is not clear why freedom of association can generate a right to discriminate on morally arbitrary grounds at all. Does not this contradict the liberal postulate of freedom and equality? And how can such discrimination be restricted to clergy appointments?

To be sure, liberals have answers to these questions but - I shall suggest - these fall foul of neutrality towards reasonable conceptions of the good. A plausible liberal defense of associational rights to discriminate might begin with a rejection of what Nancy Rosenblum called the 'congruence model', which assumes full convergence between the political ideals of justice and the more comprehensive outlooks pursued within civil society associations. ${ }^{32}$ On a more pluralist view, compatible with political liberalism, voluntary associations may enforce their doctrine on their members, even if the doctrine does not fully align with liberal values, as long as exit rights, as well as other basic rights of protection against abuse, exploitation and so forth, are protected. One implication of freedom of association is that associations must be left free to define their own commitments and doctrines. And one implication of neutrality is that the state should not meddle with substantive matters of theological competence - this is entailed by the idea of 'separation' between church and state. If all this is plausible, a defense of the ministerial exemption is available to liberals. The Catholic Church has no discretionary right to discriminate in all its employment relationships, but it can have an all-male clergy, because Catholic doctrine demands (for better or worse) that its ministers be men, and because appointment to the ministry - and the ministry itself - is an indisputably religious competence. The argument would show that the liberal demand of neutrality is met through the refusal by the state to interfere with irreducibly religious matters, and its commitment to defer to associations as to the proper scope of their competence.

But here is the challenge for neutralist liberals. The distinction between irreducibly religious' and civil interests - a distinction John Locke thought was essential to 'distinguish exactly

\footnotetext{
32 Nancy Rosenblum, Membership and Morals. The Personal Uses of Pluralism in America. Princeton: Princeton University Press, 1998, pp. 36ff.
} 
the business of civil government from that of religion' ${ }^{33}$ - is a reasonably contested matter. Churches and other religious groups have their own distinctive stance about what is a religious activity, as well as about the scope of their own competence in determining it. Consider, for example, the expansive application of the ministerial exception in the U.S.A., where the Supreme Court has deferred to churches' own definition of 'ministers', including music directors, organists, seminarians, university chaplains, and schoolteachers. The ministerial exception is often defended in jurisdictional terms, as the prerogative, held by churches, to solve their employment disputes internally. Religious groups have also argued for a broader right to discriminate on religious grounds: for example, for Catholic or Muslim schools not to have to give equal consideration to atheist teachers. Generally, religious groups have sought to employ co-religionists in the sundry faith-based activities they engage in - helping the poor, providing health and social care, running religiously-inspired commercial enterprises, educating children - because these are, for them, irreducibly religious activities.

In my view, liberals should resist this expansion, and protect the rights of employees from arbitrary discrimination. But to do so, they must recant their stance of neutrality. They must give up their pretense to defer to how associations define their own sphere of competence, and they must also accept that some religious claims are not obviously unreasonable. This is because religious believers are not challenging the priority of political values as such but, rather, identifying the specific practices and relationships to which the political values apply (or not). They disagree with liberals' more restrictive understanding of the ministerial exception, but this disagreement is rooted in a deeper ontological disagreement about the boundaries of religion - and therefore, of freedom of religious association - itself. ${ }^{34}$

Neutralist liberals so far have underestimated this difficulty. Consider, for example, Quong's answer to a related challenge by Gerald Gaus. Gaus argues that political liberalism is sectarian if it cannot be justified to those holding conservative religious views. ${ }^{35}$ Quong's reply is that those citizens - whom he calls 'All-Things-Considered-Reasoners' (ATCRs) - fail to prioritize the political conception of justice over their comprehensive or non-public reasons and, for that reason, should not be included in the constituency of public reason. Quong illustrates his argument in the following way:

'Consider an ATCR named Anna. Anna endorses the core political values of freedom,

\footnotetext{
33 John Locke, A Letter Concerning Toleration, reprinted in John Horton \& Susan Mendus (eds.) A Letter Concerning Toleration in Focus. London: Routledge,1991, p. 17.

${ }^{34}$ For further developments, see Cécile Laborde, Liberalism's Religion. Cambridge Mass., Harvard University Press, 2017, Chapter. 5

35 Gerald Gaus 'Sectarianism Without Perfection? On Quong's Political Liberalism', Philosophy and Public Issues, Vol. 2, No. 2 (Fall 2012): pp. 7-15.
} 
equality, and fairness, but she doesn't place too much weight on these political values in comparison to the values of her religious doctrine. Suppose that any plausible balance of the political values yields a right against religious discrimination in employment with an exception, let's suppose, for jobs within religious associations. The right in question thus forbids religious discrimination when hiring employees in non-religious contexts such as shops, factories, government agencies, and so on. Anna accepts that this is what is entailed when we consider the political values alone. But when she consults the full set of her views, including her religious doctrine, she arrives at the all things considered judgment that the right against such discrimination is not justified, because the requirements of her religion take precedence on this matter'. ${ }^{36}$

This is, however, a tendentious description of what ATCRs such as Anna are up to. If we modify Quong's scenario only slightly, we can show Anna to be reasonable. Suppose Anna agrees that religious discrimination is unacceptable in shops, factories and government agencies, but she also thinks that it is permissible in the case of faith-based organizations such as religious schools and hospitals. In this re-description, Anna does not let her full set of religious views take precedence over the political values (as in Quong's scenario). Rather, she holds a different view of where the line between permissible and impermissible discrimination lies. She thinks that the privileges held by religious associations such as churches (in line with what Quong calls a 'plausible' account of permissible discrimination) must be extended to a broader set of faith-based groups. This might be misguided, but it is not unreasonable. It is one - contestable - account of the scope of applicability of the political values. What is tendentious about Quong's scenario is that it is set up to show that ATCRs unreasonably prioritize their comprehensive views over the political values. But a more generous - and plausible - interpretation is that ATCRs provide a different account of where the political values apply, based on a different social ontology of religious association. Just as in the cases of abortion and same-same marriage, then, resolution by appeal to the political values of justice depends upon the prior identification of the type of entities and relationships that are justice-apt, so to say.

\section{Conclusion}

Controversies about the status of fetuses, marriage, and religious association raise profound challenges for liberal neutrality. The disagreement between liberals and their religious critics about

\footnotetext{
36 Jonathan Quong, 'Liberalism Without Perfection: Replies to Gaus, Colburn, Chan, and Bocchiola', Philosophy and Public Issues 2 (2): $51-79$ (2012), p. 55.
} 
these and other 'cognate problems' cannot be described as unreasonable, nor is it tractable in public reason. This is because while religious critics do not appeal to comprehensive religious doctrines, they appeal to different ontological accounts of natural entities and social relationships. And so do liberals. I agree with Kramer that liberal neutrality is illusory in these cases, and that liberals must articulate and defend substantive positions. But I also agree with Quong that reasonable disagreement about justice, when it cannot be resolved in public reason, threatens to undermine liberal political legitimacy. My political liberalism, therefore, is both more honest and more modest than Quong's. ${ }^{37}$ It is more honest because it is prepared to concede to religious critics that liberalism is rooted in commitments - including ontological commitments - that they might reasonably reject. Liberalism need not be comprehensive or perfectionist; but it relies on a substantively liberal - secular and individualistic - ontology. And this liberalism is more modest because it does not hold that public reason is sufficient to provide legitimacy to liberal laws. In some cases, reasonable disagreement about justice is underpinned by intractable ontological disagreements. As public reason is radically inconclusive or indeterminate about these, there is no alternative but to turn to procedural - in my case, democratic - resolutions to deep disagreement about boundaries between the right and the good, between the religious and the secular, and between questions of ontology and questions of justice.

${ }^{37}$ I say more about liberal modesty in 'Three Cheers for Liberal Modesty: A Reply to Critics', Critical Review of Social and Political Philosophy, forthcoming. 